Holburt Waring. The Farm is intended to provide young surgeons with opportunities of extending our knowledge of the biological processes which underlie the art of surgery. Already a series of experimental inquiries has been set on foot to determine how far surgical methods can be employed for the cure or relief of the graver forms of pulmonary tuberculosis. In his opening address, Sir Holburt Waring outlined some of the clinical conditions which require experimental elucidation. He cited particularly the grave mortality which still attends intestinal obstruction and the need for further study of the condition known as surgical shock. The Research Farm, which is $16 \frac{1}{2}$ miles from Charing Cross, is the gift of Sir Buckston Browne, a distinguished London surgeon and a fellow of the Royal College of Surgeons. Rather more than two years ago he gave $£ 100,000$ to his College in order that it might be able to add a research station in the country to the experimental laboratories already established in connexion with the Hunterian Museum in Lincoln's Inn Fields.

As is well known, John Hunter, the celebrated surgeon of the eighteenth century, carried on his experimental work at his farm at Earl's Court. Sir Buckston Browne wished to present a modern representation of Hunter's Earl's Court Farm to his College and chose a site in the parish of Downe, Kent, adjacent to the home of Charles Darwin. It will be remembered that in 1928 Sir Buckston purchased Darwin's home, Down House, and after restoring and endowing it, presented it to the British Association. The Research Farm is built on land which adjoins the gardens and grounds of Down House. Sir Buckston Browne has thus established side by side in Darwin's parish two bodies which encourage research, namely, the British Association for the Advancement of Science and the Royal College of Surgeons of England. Dr. O. J. R. Howarth is resident officer at Down House, while Sir Arthur Keith is in charge of the Buckston Browne Research Farm.

\section{Cancer Research}

THE tenth annual report of the British Empire Cancer Campaign notices a considerable variety of investigations into the nature, cause and treatment of cancer, which are being carried on under its auspices in different parts of the world. Three of the results obtained especially are of general interest. At the Cancer Hospital, Prof. E. L. Kennaway, Dr. J. W. Cook and their colleagues have now isolated the substance (or one of the substances) to which tar owes its peculiar carcinogenic properties: it proves to be 1:2-benzpyrene. No evidence was obtained of the presence of the dibenzanthracene which the same workers have synthesised and shown to be nearly equally active, and, along with Prof. E. C. Dodds, to have a remarkable influence on the sexual cycle in animals. It remains to be discovered whether these or similar substances are ever produced in the body and so form the intermediaries whereby chronic irritation and injury give rise to tumours. At the Middlesex Hospital, Prof. J.
McIntosh has made the notable discovery that some at least of the connective tissue tumours produced in fowls by tar can be transmitted by a filtrable agent. The experimental growths thus come into line with the natural bird tumours which have been so much studied. No clear mammalian tumour has yet been shown to be certainly filtrable.

\section{A Virus from Influenza Patients}

The causation of epidemic influenza has proved a perplexing problem for the bacteriologist. Of the bacterial organisms associated with the disease, Pfeiffer's influenza bacillus, the most frequent, and others do not appear to be capable of reproducing the cardinal features of the disease, but only some of the secondary symptoms. Another difficulty encountered is the insusceptibility of most animals to human influenza, the so-called influenzas of animals being distinct from the human. Latterly, attempts have been made to detect a virus in the disease, hitherto with little or no success, but in a recent communication, Smith, Andrewes and Laidlaw describe results obtained with ferrets (Lancet, July 8, p. 66). A febrile disease is produced in ferrets by the intranasal instillation of filtrates of throat washings obtained from influenza patients, which is transmissible serially in ferrets either by contact or by intranasal instillation of virus material from infected ferrets. Filtration was conducted through 'Gradocol' membranes so that the filtrate is bacteriafree. Throat-washings from healthy persons and influenza convalescents caused no illness in ferrets. The disease in ferrets has some likeness to human influenza, with nasal and pulmonary catarrh and occasionally a relapse. The blood-serum of a ferret that has recovered, and also that of recovered human cases, neutralises the virus. The virus of swine influenza, described by Shope, has a close antigenic relationship with the influenza virus, and induces a disease in ferrets very like that produced with the influenza virus. A prima facie case has indirectly been made out for an attempt to transfer the ferret disease back again to man, and a technique has been discovered which can be exploited fruitfully when the next human epidemic occurs.

\section{Massive Radium Unit for Treatment}

Ix may be recalled that the Radium Committee decided last year to withdraw and dismantle the four-gram radium 'bomb' used for massive radiation at Westminster Hospital. Some doubt was expressed at the time of the wisdom of this step, but a conference called by the Royal Colleges of Physicians and Surgeons endorsed the policy, at the same time appointing a committee of experts to reconsider the case for mass radiation. After visits to radium treatment centres abroad, the committee reported that it is desirable that a radium unit of not less than five grams should be established, so that research can be undertaken on the value of what is best termed 'beam' therapy. For this purpose, a representative governing body with Sir Frederick Gowland Hopkins as chairman was constituted. After negotia- 